\title{
Optimizing Access to Financial Capital of Creative Economy for Startups Towards Global Competitiveness
}

\author{
Sugeng Santoso \\ Master of Management, Mercu Buana University, \\ Jakarta 11480, Indonesia \\ sugeng.santoso@mercubuana.ac.id
}

\begin{abstract}
The lack of understanding of the financial capital of the creative economy regarding non-bank financial institutions limits the growth of Indonesia's creative economy. Strategies through policies, capital owners, creative economy players and bring together capital owners with players. The capital of the creative economy is represented on the criteria: entrepreneurial characteristics, product/service characteristics, market characteristics, and financial characteristics. The method used is a qualitative analysis and quantitative analysis which starts from data collection, data analysis, participatory discussion, drawing conclusions, formulating policies and stakeholder synergy. The startup mentoring scoring instrument is a framework for investor's decision making to invest in the startup. 3 scoring elements of mentoring startup scoring: Product \& key person with a weight of 55\%, Traction with a weight of $25 \%$, and Investment with a weight of $20 \%$. Primary data were obtained by participatory observation, field studies, and key informant interviews through startup mentoring programs, workshops, and startup competitions. Results: Among 20\% of startups pitched in front of investors, there are $11 \%$ of startups that investors interested in and got funding from a consortium of Indonesian and foreign venture capital companies. Matchmaking activities increase added value, and the implemented policy also increases added value.
\end{abstract}

Keyword - Non-banking capital access; startups; ecosystems; program strategies.

\section{INTRODUCTION}

The creative economy sector is expected to be able to increase the contribution of the Gross Domestic Product (GDP) in the Creative Economy (Ekraf) sector, employment of the Ekraf sector, the number of businesses and an increase in exports of products or services. The creative economy has characteristics related to value chains that contain intellectual property. Capital is one of the crucial things in building a creative-based business. The creative economy at least experiences a number of obstacles in terms of funding. First, the majority of creative economy businesses are unbankable: they have not been able to meet the requirements desired by banks. Second, the assets of the creative economy business players are intangible: those that are not physical in nature so that financial institutions cannot be accepted at this time. As a result of the intangible creative economic assets, often financing in this sector is considered to have a high enough risk and difficult to predict. In addition, cash flow in some sectors of the creative economy is also unstable. Sometimes it is very high, but at other times it is low.

Some things related to the lack of understanding of the capital of the creative economy, especially from non-bank financial institutions, especially venture capital, which limits the creative economic growth space of Indonesia. Therefore, communication and coordination with stakeholders such as the Financial Services Authority (OJK), investors, prospective business partners, creative economy players, and the need of incentives for investors or investors who will and have invested in the creative economy sector, including for start-ups, need to be improved.

When viewed from the perspective of Business Phase Financing for creative economic players, they are grouped in the initial phase, the development phase, the consolidation phase, and the saturation phase. In the initial phase of startup or startup companies generally or commonly referred to like the idea phase and the seed phase as well as some early phases. In the idea and seed phase, a non-banking capital source scheme is required, 
including (1) government funds (government assistance); (2) the Corporate Environment Development Program; (3) investment from business incubators, angel investors and (4) own capital, crowdfunding from friends, relatives, and others. In this phase, the possibility of obtaining financial capital resources from venture capital is still small, because the risk is still high in passing the valley of death of the business (the valley of death).

The Challenge of Capital Access Ekraf is illustrated from the results of a survey conducted by the Central Statistics Agency in 2016, namely the capital status of creative economy entrepreneurs who tend to use their own capital rather than utilizing investment facilities, schemes or loans. From this phenomenon, it is necessary to carry out a special strategy to provide attractive facilities for creative economy entrepreneurs to utilize capital assistance from the government and non-government, especially investment schemes, government assistance, and loan schemes.

Research of the Access to Financial Capital Program Strategy, which is to bring together owners of funds or investors with creative economic players. There are four strategies carried out in the capital access program, which are related to (1) policy, (2) the side of the capital owner (supply side), (3) the side of the creative economy (demand side) and (4) bringing together the supply side and demand side (matchmaking) including support activities. Figure 1 below explains the access to capital.

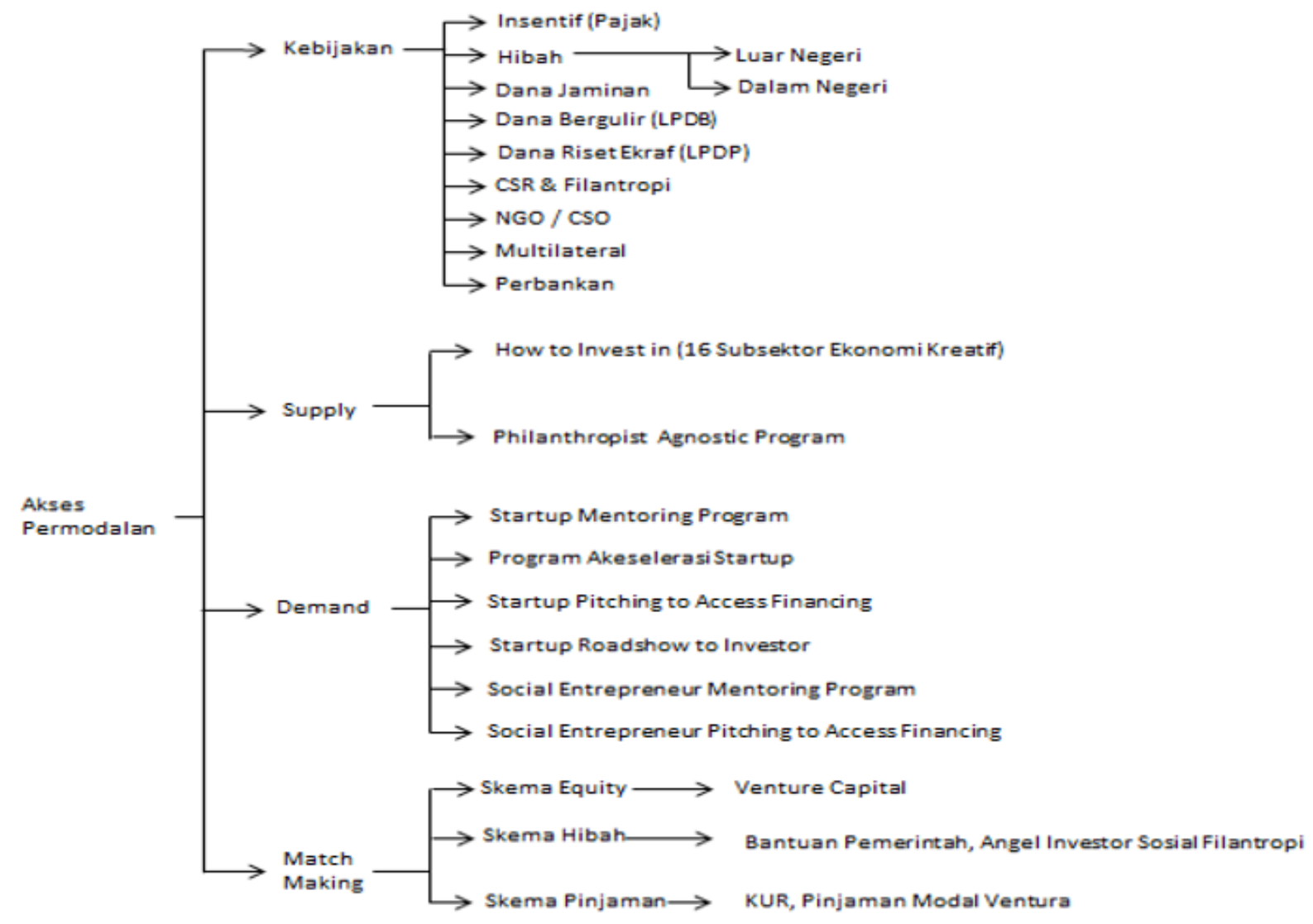

Figure 1 Conception and Implementation of the Creative Economy Capital System Source : Bekraf, (2017), modified

Demand-side is facilitation for creative economic players in the form of capacity building, especially on matters relating to business knowledge and financial management. Demand-side activities include workshops, conferences, competitions, talk shows, pitching and classes in various regions in Indonesia which are carried out to develop access to financial capital for creative economic players.

Supply-Side is an approach to capital owners by conducting discussions, consultancy, or advocacy so that capital owners know and understand, so they are interested in channeling their capital to the creative economy sector. Examples of supply-side activities are how to invest in (16 sub-sectors) and philanthropic agnostic programs.

Match Making is an interaction or intermediation between the owner of the capital with creative economic players. An example of a matchmaking activity for an investment scheme is pitching business which is facilitated to bring investors together with startups. Examples of matchmaking activities for investment schemes through business pitching are facilitated to bring investors together with startups, including Pitching at Final Startup Pitch 
Day, Pitching at IdeaFest, Pitching at Foodstartup.

A policy is a series of instructions from the decision-maker to the policy implementer that explains the objectives and ways to achieve them. For the policy to function effectively, it is necessary to have an "instrument or tool" for its policy (policy tools or instruments), which is a set of steps or actions taken by the government to realize the established policy. Each (or a combination of several) policy instruments usually involves (contains) at least 3 (three) aspects, namely: 1) Legal devices: concerning the legal aspects that support it (underlying it); 2) Institutional setting: relating to the institutional structure (organization) involved, function and organization (structure and relationship or interaction between players); 3) Operational mechanism (operational mechanism): related to patterns, methods, and procedures as well as the implementation process in practical implementation.

Sources of capital, in general, can come from equity or private capital and loans both bank loans and nonbank loans, for example from non-banking creditors and investors. The financing problems that are often faced by creative economic players include (1) unable to access loans from the banking sector because the characteristics of the creative industry are intangible so that they cannot become collateral and (2) business risks that cannot be measured and estimated properly. Therefore the creative economy needs a financial institution that can provide capital to finance the idea creation process. Funding sources are divided into two types namely public which consists of 1) Public Funding (APBN: Fiscal incentives, International Grants, Ministry / Government Institutional Expenditures, Financing: Interest subsidies, Guarantee funds, Revolving funds, APBD: Derived from provincial government funds, district or city government); 2) Non-Public: Business (Corporate Social Responsibility / CSR), Philanthropy, Crowdfunding, Non-Government Organizations (NGOs), Multilateral, banking, Non-Banking and Financial Technology, Venture Capital, Crowdfunding Equity, Stocks, Angel Investors.

If based on the scheme, the type of funding is divided into equity capital, grants, and loans. The following is a quick look at some funding alternatives consisting of 1) a grant scheme which is funding production activities at the idea and seed stage can also be through funding that is of an aid or grant nature. Grant funds can come from corporations, philanthropy, government, crowdfunding; 2) Corporate Social Responsibility (CSR) \& Philanthropy. Private sector participation and synchronization in funding schemes through CSR and philanthropy can be financing solutions for the development of the creative economy; CSR is an initiative and effort of the private sector in conveying concern for social issues in the community. It can be directed to help the country achieve its national agenda targets. Philanthropy is the voluntary act of giving money or other forms (charity) to others voluntarily and without pressure to the needy; 3) Crowdfunding which is defined as collective funding in general, the funding mechanism by the public which is mediated by certain portals or websites. Crowdfunding provides an alternative source of new funding. Crowdfunding service providers act as vehicles to access resources by utilizing social networks and online media; 4) Government Assistance that does not meet the criteria for social assistance provided by the Government to individuals, community groups or government / non-government institutions; 5) Loan schemes that can come from various sources, including from LPEI (Indonesian Export Guarantee Agency), LPDB (Revolving Fund Management Agency), KUR (People's Business Credit), partnership programs from SOEs coordinated by the Ministry of SOEs and commercial loans others such as the People's Business Credit Program (KUR), the Indonesian Export Financing Agency (LPEI), the Revolving Fund Loan Institution (LPDB); 6) Non-Bank Financial Institutions - PBMT Ventura which is a non-bank financial institution that is managed with sharia principles. This institution provides financial services for micro and small entrepreneurs that are channeled through the BMT network. Other products are technical assistance, research, innovation, and networking, 7) BUMN Partnership Program which is an important source of financing for the success of a business. One alternative source of non-banking financing that can be utilized by businesses is the Partnership and Community Development Program Fund from SOEs (PKBL).

The Investment Scheme consists of 1) Venture Capital which is a financing business through capital participation and/or financing for a certain period in the context of developing a business partner or debtor; 2) Equity Crowdfunding which is equity, investment or called Equity-based crowdfunding is a concept in which creative entrepreneurs offer ownership rights in the form of shares in return for contributions made publicly. 3) Angel Investors are individuals or groups of people who have the financial strength and are willing to provide an injection of funds for a new company; 4) Financial Technology (Fintech) which is explained in the figure below. Of the 6 areas illustrated, only 4 areas are related to capital access, namely insurance, deposits \& lendings, capital raising, and investment management. 


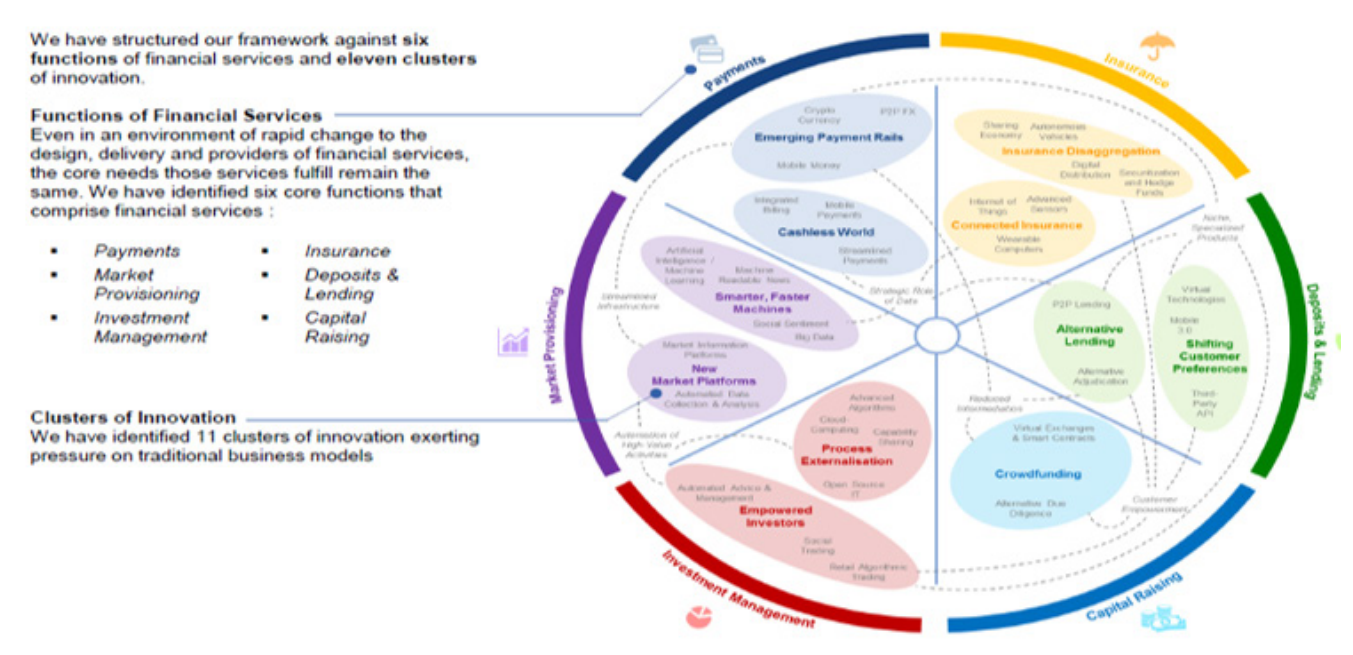

Figure 2 Fintech Industrial Area

Source: Acknowledgement World Economic Forum, 2016

Information technology has been used to develop the financial industry that can encourage the growth of alternative financing for the community. The financial capital of a creative economy that is competitive is represented by the criteria of startups that are eligible to use venture capital, including: (1) Characteristics of entrepreneurs; (2) Product / Service Characteristics; (3) Market Characteristics; (4) Financial Characteristics (Hudson and Evans in the Journal of Economic and Social Policy, Vol.10, Article 3, 2005).

Regarding supply-side capital access, an approach and introduction to sub-sectors, value chains, and creative economic sector policies are carried out. Meetings with stakeholders and Engagement of Stakeholder Commitment Support by representatives of venture capital, banking, financial technology, philanthropic associations, angel investors, CSR, LPDB, Venture PBMT, and others. In addition, a scenario is discussed to invest in startups that win the competition by first mentoring the capital owner and at the same time making a draft selection and curation mechanism for startups participating in the competition.

Related to demand-side capital access, various kinds of program socialization, workshops, making pitches \& pitching, conferences, competitions in various regions in order to increase the capacity of creative economic players. Included in the demand side is strengthening the capacity of creative economic players in financial management, innovation, and entrepreneurial management, risk management and others.

Through a series of meetings, an Investment Matchmaking Instrument was created through business pitching that brought investors together with startups. Startup Mentoring Assessment Scoring is is a framework of investor decision making to invest in startups, where previously investors were given the opportunity to get to know startups through mentoring programs. There are 3 elements of Mentoring Startup Assessment Scoring, namely (1) Product \& Key Person; (2) Traction; and (3) Investment where the weight for Product \& Key Person is $55 \%$; Traction is $25 \%$ and Investment is $20 \%$. 
Table 1 Startup Mentoring Assessment Scoring

\section{SCORING SHEET MENTORSHIP STARTUP}

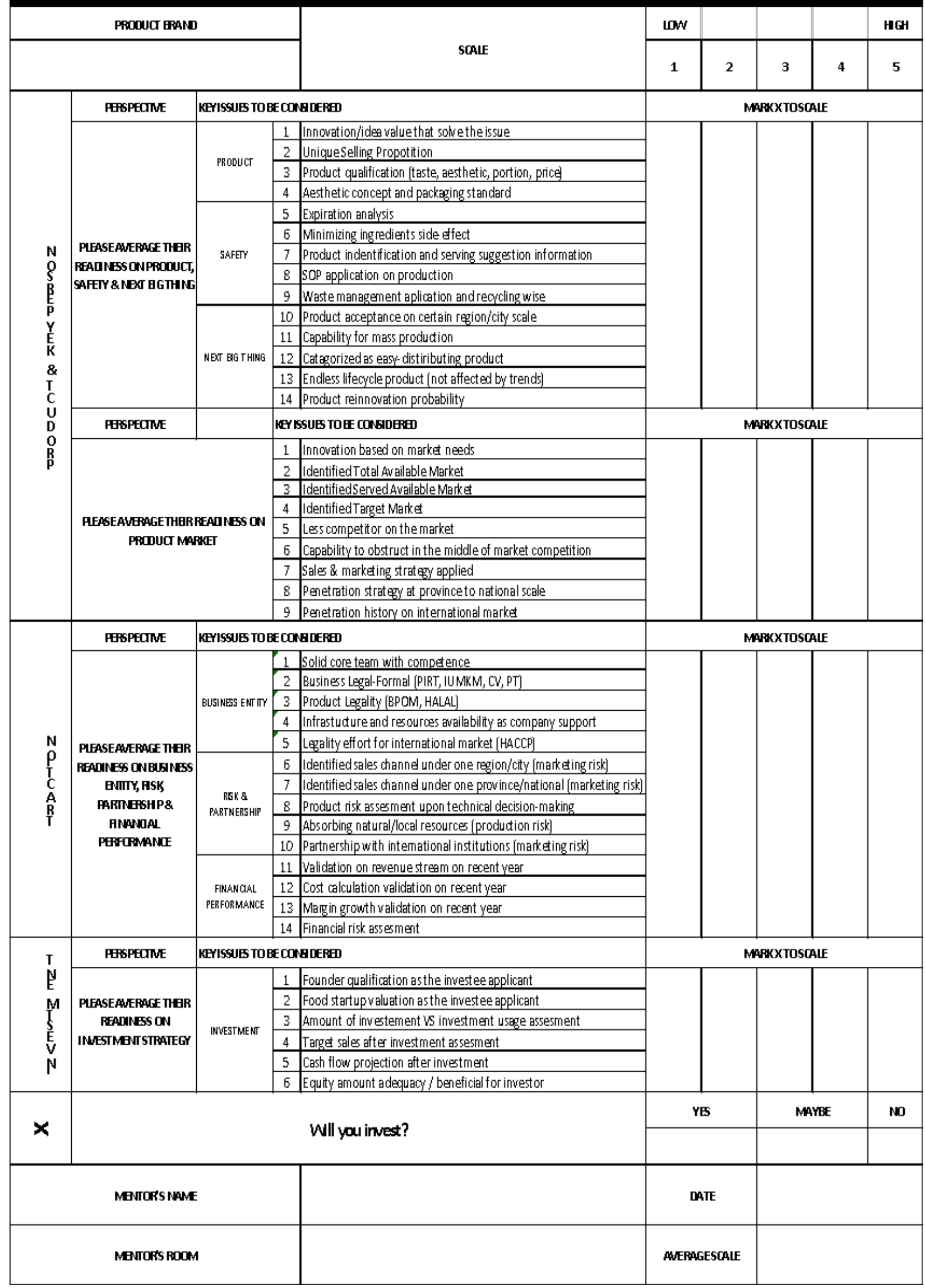

Source : Food Startup Indonesia (2017), modified 


\section{METHODS}

The method used is a qualitative analysis that starts from data collection, data analysis, discussion of participation, focus group discussion, interactive analysis, drawing conclusions, and making (recommendations) policy and stakeholder synergy or collaboration.

Primary data obtained by participatory observation (participatory observation), field studies and interviews with key informants (key informants). Activities undertaken in obtaining primary data include (1) Startup Mentoring Program; (2) Workshop: Valuation, Equity Stake Offering \& Negotiation; (3) Startup Competitions and Conferences. Secondary data sources are used to support information obtained from source of references, literature, previous research, books, reports on activities held by libraries and so on. To assess the validity of qualitative research data, conducted: 1) Triangulation which in this credibility test is interpreted as checking data from various sources in various ways and at various times. Triangulation of multiple researchers is the involvement of several researchers in the analysis process in a Focus Group Discussion (FGD) by using professionals who master specific techniques with the belief that experts from different techniques bring different perspectives; 2) Using reference material referred to by reference material here is a support to prove the data that has been found by researchers. The references used in this study are in the form of interviews and documentation; 3) Conduct peer debriefing Examining data by conducting discussions, exposing temporary results or the final results obtained by discussions with peers. 4) Conduct a member check to review the results carried out by the FGD resource person.

\section{RESULT AND DISCUSSION}

Capital owners include venture capital associations, banks, financial technology, and financial technology company associations, philanthropic associations, angel investors, corporate Social Responsibility (CSR) companies, LPDB (Revolving Fund Management Institution), PBMT Ventura (Capital of Baitul Mal wa Tamwil Ventura) committed to being a mentor and investing capital in an attractive startup, participating in organizing competitions, startup conferences in order to support a conducive startup ecosystem.

From the demand side, data collected from various non-banking capital access activities for startups from 2016 to 2017 amounted to 100 startups (30 Pitch Day Startups; 40 Indonesian Food Startups; 30 Startup World Cups). Of the 100 startups collected, 20 startups were selected in matchmaking through a startup mentoring program.

The startup follows up on the mentoring program by i) making improvements is advising the mentoring and continuing to develop (making continuous improvement); ii) do business matching with the link obtained; iii) complete the product; iv) grow our business, and pivot to reach revenue; v) run the business and prepare the product for even better.

Capital access activity from the supply side is expected to make capital owners: Commit to being willing to become a mentor and invest their capital in the startup. The owners of capital include venture capital companies, banking, financial technology, philanthropic associations, angel investors, CSR, LPDB, PBMT Ventura.

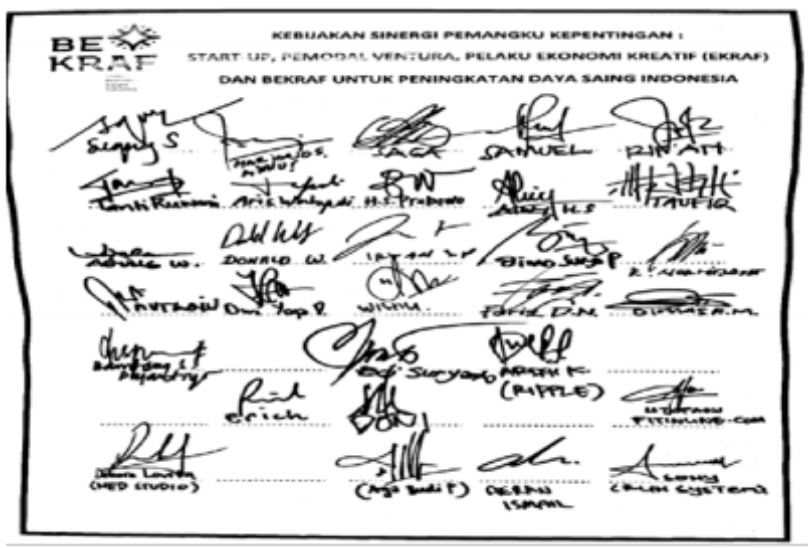

Figure 3 Sigantures of a Commitment to Stakeholder Synergy Policy and BEKRAF to Improve Indonesia's Competitiveness 
Matchmaking capital access activities are expected to increase the added value of both startups and capital owners, including i) provisioning pitching preparation \& suggestions to fix problems in startup; ii) how to pitch in a good way; iii) to gain a deep understanding of how to raise funds, share knowledge, fundraising, networking; iv) networking with player and investor industries; v) understand market needs \& investor desires, and expand the network.

Table 2 Overview of Startup Characteristics of Mentoring Program Participants

\begin{tabular}{|c|c|c|c|c|c|c|c|}
\hline No & Platform & Catagories & $\begin{array}{c}\text { Business } \\
\text { Model }\end{array}$ & Revenue Model & Differentiation & Tractions & $\begin{array}{c}\text { Funding } \\
\text { Stage }\end{array}$ \\
\hline 1 & $\begin{array}{l}\text { Website \& Apps } \\
\text { (Android \& } \\
\text { iOS) }\end{array}$ & Healthtech & B2B \& B2C & Subscription & $\begin{array}{l}\text { Can be access online, } \\
\text { low price, easy to } \\
\text { use, \& standardized. }\end{array}$ & $\begin{array}{l}1.500 \text { customer base } \& \\
200 \text { active users } \\
(\text { Aug }- \text { Sept } 2016)\end{array}$ & $\begin{array}{c}\text { Bootstrap, } \\
\text { Angel Investor }\end{array}$ \\
\hline 2 & $\begin{array}{l}\text { Website \& Apps } \\
\text { (Android \& } \\
\text { iOS) }\end{array}$ & Travel & $\mathrm{B} 2 \mathrm{~B}$ & $\begin{array}{l}\text { Subscriptions based } \\
\text { on hotel number of } \\
\text { rooms }\end{array}$ & $\begin{array}{c}\text { Low price, quality } \\
\text { service, more feature }\end{array}$ & $\begin{array}{l}48 \text { Hotel } \\
\text { (Jun - Sep 2016) }\end{array}$ & $\begin{array}{l}\text { Loan without } \\
\text { interest }\end{array}$ \\
\hline 3 & Website & E-Commerce & $\mathrm{B} 2 \mathrm{~B}, \mathrm{~B} 2 \mathrm{C}$ & $\begin{array}{l}\text { Margin from each } \\
\text { item (ranged from } 10 \\
\text { to } 40 \% \text { of prices) }\end{array}$ & $\begin{array}{c}\text { Added value (giving } \\
\text { items to children on } \\
\text { every purchase) with } \\
\text { same prices. }\end{array}$ & $\begin{array}{l}332 \text { items sold } \\
\text { (Aug-Sep 2016) }\end{array}$ & $\begin{array}{c}\text { Seed (Angel's) } \\
\& \\
\text { A Series }\end{array}$ \\
\hline 4 & $\begin{array}{l}\text { Hardware, } \\
\text { Website \& Apps } \\
\text { (Android \& } \\
\text { iOS) }\end{array}$ & $\begin{array}{l}\text { Internet of } \\
\text { Things }\end{array}$ & $\mathrm{B} 2 \mathrm{~B}, \mathrm{~B} 2 \mathrm{C}$ & $\begin{array}{l}\text { Device Selling, } \\
\text { subscription, } \\
\text { maintenance fee }\end{array}$ & $\begin{array}{l}\text { Focused on shrimp } \\
\text { farming, affordable, } \\
\text { more features (data } \\
\text { analysis \& decision } \\
\text { support maker) }\end{array}$ & $\begin{array}{l}10 \text { pilot projects, } \\
5 \text { devices used \& } \\
2 \text { devices sold. } \\
\text { (Mar-Aug 2016) }\end{array}$ & $\begin{array}{l}\text { Bootstrap, } \\
\text { looking for } \\
\text { seed and A } \\
\text { Series) }\end{array}$ \\
\hline 5 & Website & Healthtech & $\mathrm{B} 2 \mathrm{~B} \& \mathrm{~B} 2 \mathrm{C}$ & $\begin{array}{l}\text { Revenue sharing, } \\
\text { conventional, } \\
\text { training, } \\
\text { hypnotherapy. }\end{array}$ & $\begin{array}{l}\text { Low price, high } \\
\text { quality service \& one } \\
\text { to one replacement. }\end{array}$ & $\begin{array}{l}2.363 \text { friends Facebook } \\
\& 35 \text { Active Users } \\
\text { (Aug - Sep 2016) }\end{array}$ & Seed \\
\hline 6 & $\begin{array}{l}\text { Website, SDK, } \\
\text { Hardware }\end{array}$ & $\begin{array}{l}\text { Hardware IoT } \\
\text { (Internet of } \\
\text { Things) }\end{array}$ & $\begin{array}{l}\mathrm{B} 2 \mathrm{~B}, \mathrm{~B} 2 \mathrm{C} \text {, } \\
\text { End to End }\end{array}$ & $\begin{array}{l}\text { Selling hardware } \\
\text { pack, Subscription }\end{array}$ & $\begin{array}{c}\text { Provides hardware } \\
\text { devices complete } \\
\text { with mobile backend } \\
\text { as a service (mBaaS) }\end{array}$ & $\begin{array}{l}\text { Hardware: } \\
+1.000 \text { device sold; } \\
\text { Backend: } \\
+1.300 \text { user dev; } 700 \\
\text { mobile app manage. }\end{array}$ & $\begin{array}{l}\text { Pre-Seed } \\
\text { (Angel), Seed } \\
\text { Investment }\end{array}$ \\
\hline 7 & Website & $\begin{array}{l}\text { Culinary, } \\
\text { Citizen People } \\
\text { Metropolitan }\end{array}$ & $\mathrm{B} 2 \mathrm{~B}, \mathrm{~B} 2 \mathrm{C}$ & Selling product & $\begin{array}{l}\text { Medium price, } \\
\text { uniquely package, } \\
\text { delicious, exclusive. }\end{array}$ & $\begin{array}{l}\text { Average Selling } 1.500 \\
\text { pax/months from Des to } \\
\text { Aug } 2016 \text {. }\end{array}$ & $\begin{array}{c}\text { Seed (Angel's) } \\
\& \\
\text { A Series) }\end{array}$ \\
\hline 8 & $\begin{array}{c}\text { Apps } \\
\text { (Android \& } \\
\text { iOS) }\end{array}$ & $\begin{array}{l}\text { Food, Fashion, } \\
\text { Entertainment, } \\
\text { Health, \& } \\
\text { Beauty }\end{array}$ & $\mathrm{B} 2 \mathrm{C} \& \mathrm{~B} 2 \mathrm{~B}$ & $\begin{array}{c}\text { Premium } \\
\text { membership,Ads. }\end{array}$ & $\begin{array}{l}\text { More selections, } \\
\text { offers workforce, } \\
\text { and help merchant, } \\
\text { unique user one user } \\
\text { for one best deals, } \\
\text { offline exclusive } \\
\text { engagement program }\end{array}$ & $\begin{array}{l}300+\text { merchant join } \\
\text { in one month, } 2773 \\
\text { members, from May } \\
2016,216 \text { convert to } \\
\text { annual member, } 8 \% \\
\text { convention rate from free } \\
\text { user to member. }\end{array}$ & $\begin{array}{l}\text { A Series / } \\
\text { Seeds }\end{array}$ \\
\hline 9 & $\begin{array}{l}\text { Website \& } \\
\text { Mobille App } \\
\text { (Android \& } \\
\text { iOS) }\end{array}$ & $\begin{array}{l}\text { Education } \\
\quad(\text { SaaS })\end{array}$ & B2B2C & Subscriptions & $\begin{array}{l}\text { High Quality } \\
\text { Service, Using } \\
\text { Mobile Apps and } \\
\text { SMS Gateway. }\end{array}$ & $\begin{array}{l}\text { Revenue from } \\
\text { subscription } \\
\text { (Aug - Sept 2016) }\end{array}$ & Seed (Angel's) \\
\hline 10 & $\begin{array}{l}\text { Website \& Apps } \\
\text { (Android \& } \\
\text { iOS) }\end{array}$ & $\begin{array}{c}\text { Fashion, Male } \\
\text { (17-35 Years } \\
\text { Old })\end{array}$ & $\mathrm{B} 2 \mathrm{C}$ & $\begin{array}{l}\text { Selling Product } \\
\text { Fashion }\end{array}$ & $\begin{array}{l}\text { World's fastest } \\
\text { production process, } \\
\text { best quality, } \\
\text { thousands of design } \\
\text { combinations, money } \\
\text { back guarantee. }\end{array}$ & $\begin{array}{l}\text { Revenue from } 2013 \text { up } \\
\text { to } 2016 \text {. Profit from } 15 \text { - } \\
20 \% \text { from revenue. }\end{array}$ & Seeds \\
\hline 11 & Website Fastion & $\begin{array}{l}\text { Fashion } \\
\text { Service }\end{array}$ & $\mathrm{B} 2 \mathrm{~B}$ & Commission & $\begin{array}{l}\text { Low Minimum } \\
\text { Order, Quality } \\
\text { Service, Competitive } \\
\text { Price, Revision } \\
\text { Guarantee, Economy } \\
\text { Sharing Concept. }\end{array}$ & $\begin{array}{l}\text { All in Mar-Aug } 2016 \\
100+\text { fashion, Brand } \\
\text { Satisfied, } 30 \%+\text { reorder, } \\
400+\text { product delivered, } \\
500+\text { home based tailor } \\
\text { registered. }\end{array}$ & $\begin{array}{c}\text { Seed (Angel's) } \\
- \text { still } \\
\text { fundraising }\end{array}$ \\
\hline 12 & $\begin{array}{l}\text { Website \& Apps } \\
\text { (Android) }\end{array}$ & $\begin{array}{c}\text { Social } \\
\text { Media and } \\
\text { Community }\end{array}$ & $\mathrm{C} 2 \mathrm{C}, \mathrm{B} 2 \mathrm{C}$ & Premium \& Ads. & $\begin{array}{l}\text { Based on popularity, } \\
\text { gamification } \\
\text { features, local } \\
\text { content (language } \\
\text { sticker, etc.). }\end{array}$ & $\begin{array}{l}500.000+\text { monthly page } \\
\text { views and 23.000+ } \\
\text { Monthly Active Users. } \\
70.000 \text { registered users. }\end{array}$ & $\begin{array}{l}\text { Strategic } \\
\text { partner }\end{array}$ \\
\hline
\end{tabular}




\begin{tabular}{|c|c|c|c|c|c|c|c|}
\hline 13 & $\begin{array}{l}\text { Website \& Apps } \\
\text { (Android \& } \\
\text { iOS) }\end{array}$ & $\begin{array}{l}\text { Muslim in the } \\
\text { World }\end{array}$ & $\mathrm{B} 2 \mathrm{C}$ & $\begin{array}{c}\text { Premium, } \\
\text { Scholarship, Ads. }\end{array}$ & $\begin{array}{l}\text { Better content, } \\
\text { higher quality } \\
\text { cheaper more } \\
\text { effective and more } \\
\text { efficient. }\end{array}$ & $\begin{array}{lr}\text { As Per Sep } & 2016, \\
650.000+\text { users, } & 4.500+ \\
\text { daily active } & \text { users, } \\
2,700+\text { buyers. } & \end{array}$ & Seed funding \\
\hline 14 & $\begin{array}{l}\text { Website \& Apps } \\
\text { (Android \& } \\
\text { iOS) }\end{array}$ & AdTech & $\mathrm{B} 2 \mathrm{C}$ & $\begin{array}{l}\text { Commission \& } \\
\text { Targeted Ads. }\end{array}$ & $\begin{array}{l}\text { Low Price, relevant } \\
\text { audiences }+ \text { targeting } \\
+ \text { measurability. }\end{array}$ & $\begin{array}{l}19.000 \text { tracing users } \\
\text { (Jul 2015 - Aug 2016), } \\
\text { 50.000 Registered Users. }\end{array}$ & Seed-funded \\
\hline 15 & Website \& Apps & Gen Y \& Z & $\mathrm{B} 2 \mathrm{C}$ & $\begin{array}{l}\text { Production margin } \\
\text { from production cost }\end{array}$ & $\begin{array}{l}\text { Low price, high } \\
\text { quality, free delivery } \\
\text { cost, many design } \\
\text { templates. }\end{array}$ & $\begin{array}{l}\text { - More than } 1,856 \text { orders } \\
\text { processed, } 600 \% \text { growth } \\
\text { in } 1 \text { year (from June } \\
2015 \text { ) } \\
\text { - More than } 5.000 \\
\text { average unique visitors/ } \\
\text { month. }\end{array}$ & nothing \\
\hline
\end{tabular}

Source: Secondary data, processed

Based on this analysis, it is evident that the first element (the formidable team and the product it produces) is very significant (weighting 55\%), while the traction (trace evidence that the product is in demand by the market and already has a user or user downloaded, there is revenue, user likes, and innovating) weighs $25 \%$. During this time many startup products are in the form of prototypes (products that are still in the development stage) or MVP: Minimum Viable Products (Products that are ready with minimal features that aim to be tested to the market), therefore successful startups usually make improvements to their products arrived at MVP and traction. Whereas the third element is Investment that the Creative Economy Startup has received capital or investment, and the latest has also received funding from a consortium of Indonesian and foreign venture capital companies.

\section{CONCLUSION}

Optimizing access to financial capital of creative economy for startups towards global competitiveness will be realized if 1) There is an increase in the capacity of creative economy players related to business knowledge and financial management through conferences, competitions, pitching: a) pitching preparation \& suggestions to fix problems in startups; b) how to pitch in a good way; c) networking, knowledge sharing, fundraising; d) networking with player and investor industries; e) understand market needs, investor desires, expand networks; 2) Increasing the added value of creative economy players after increasing their capacity makes startups competitive; 3) Committed capital owners are willing to become mentors and invest their capital in startups. Supply Side is an approach to capital owners by conducting discussions, consultancy, or advocacy so that capital owners know, understand and are interested in channeling their capital to the creative economy sector; 4) Matchmaking activities increase the added value of both startups and capital owners. Matchmaking is an interaction or intermediation between capital owners and creative economic actors such as pitching business which is facilitated to bring investors together with startups; 5) Policies to increase added value for both startups and capital owners. The policy is a series of instructions from the decision-maker to the policy implementer that explains the objectives and ways to achieve it, including Regulation of the Head of Creative Economy Agency Number 10 the Year 2016 is a policy on Government Assistance to support the capital of startups during the seed phase or initial funding for startups has gone through the curation committee evaluation; 6) Creative Economy Startups have received capital or investment, and most recently also received funding from a consortium of Indonesian and foreign venture capital companies. 


\section{REFERENCES}

Andra, Yudistira. (2016). Penanda-tanganan Perjanjian Kerja Sama Badan Ekonomi Kreatif(Bekraf) dengan Lembaga Pengelola Dana Bergulir - Koperasi dan Usaha Mikro, Kecil dan Menengah (LPDB - KUMKM).

Anon. (1969). 19-th Annual Book of ASTM Standards Part 17, ASTM, Philadelphia, p.636.

Arnold, Erik., Boekholt, Patries., Deiaco, Enrico., McKibbin, Shonie., Mothe, John de la., Paul, Simmonds., Stroya,James., \& Zaman,Rapela. (2003). Research and Innovation Governance in Eight Countries: A Meta-Analysis. Work Funded by EZ (Netherlands) and RCN (Norway), Technopolis.

Bank Indonesia, Departemen Pengembangan UMKM. (2015). Kajian Peningkatan Akses Pembiayaan Bagi Industri Kreatif Di Indonesia Sektor.

Bappenas. (2008). Analisis dan Formulasi Kebijakan Pemanfaatan Sumber-Sumber Pendanaan Non-APBN.

Dian, Bernadheta. (2016). Bekraf Gandeng LKNB Tingkatkan Kualitas Pelaku Ekonomi Kreatif. http://www.harianjogja.com/Bekraf-Gandeng-LKNB-Tingkatkan-Kualitas-Pelaku. (Accessed in 10 December 2016).

Direktorat Akses Non Perbankan, Deputi Akses Permodalan, Badan Ekonomi Kreatif. (2017). Akses Permodalan, Tantangan \& Telaah Strategi, ISBN 978-602-60735-0-1.

Hudson, \& Evans. (2005). Journal of Economic and Social Policy. Vol. 10 No. 3.

Imam, Saputro. (2016). Badan Ekonomi Kreatif Jembatani Pelaku Startup dengan Pemilik Modal.

J.J. Favier, D. Camel. (1986). Proceedings of the Eight International Conference on Crystal Growth, York, U.K., p. 50.

L. Weiss. (1999). Instruction to Authors, Elsevier Publishing, http://www.elsevier.com/authors.html. (Accessed in 1 Januari 2000).

Lestari, Sri. (2016). Bekraf Pertemukan "Startup" dan Investor dalam "Startup Pitch Day" di Bali.

Mimi, Zulaikha. (2016). Dongkrak Investasi untuk Startup Indonesia, Bekraf Gelar Startup Pitch Day.

Nainggolan Ferry. (2016). BEKRAF Kerjasama Dengan Startup World Cup 2017.

Nicholson, R.D. (1980). International Structures In Nickelbased Transitions Joints After Long Term Service, Report RD/M/N1131, Central Electricity Generating Board, Marchwood.

Ramos, R. (1992).Thesis, College van Dekanen, University of Twente, The Netherland.

Sze. S.M. (1981). The Physics of Semiconductor Devices, Wiley, New York, p.245.

World Economic Forum. (2016). Acknowledgement.

Yamagishi,H., Hiroe,A., Nishio,H., Miki,K., Tsuge,K., \& Tawada,Y. (1993). U.S. Patent No. 5264710.

Yud. (2016). Bekraf-Kinara Indonesia Gelar Startup Pitch Day. 